\title{
Interstitial granulomatous dermatitis with arthritis
}

INSERM

\section{Source}

INSERM. (1999). Orphanet: an online rare disease and orphan drug data base. Interstitial granulomatous dermatitis with arthritis. ORPHA:79099

Interstitial granulomatous dermatitis with arthritis is a rare rheumatologic disease characterized by the occurrence of inflammatory arthritis in association with large, erythematous, symmetrical cutaneous lesions (ranging from typical, but infrequent, cord-like lesions on the flanks to more common violaceous plaques on the trunk and limbs) featuring a typical histologic infiltrate mainly constituted of histiocytes. 